\title{
Frames (Automated Content Analysis)
}

\section{AUTHOR}

Valerie Hase

\section{KEYWORDS}

framing, semantic networks, LDA topic modeling, $k$ means clustering, network analysis

\section{BRIEF DESCRIPTION}

Frames describe the way issues are presented, i.e., what aspects are made salient when communicating about these issues.

FIELD OF APPLICATION/THEORETICAL FOUNDATION The concept of frames is directly based on the theory of "Framing". However, many studies using automated content analysis are lacking a clear theoretical definition of what constitutes a frame. As an exception, Walter and Ophir (2019) use automated content analysis to explore issue and strategy frames as defined by Cappella and Jamieson (1997). Vu and Lynn (2020) refer to Entman's (1991) understanding of frames.

The datasets referred to in the table are described in the following paragraph:

Van der Meer et al. (2010) use a dataset consisting of Dutch newspaper articles (1991-2015, N = 9,443 ) and LDA topic modeling in combination with k-means clustering to identify frames. Walter and Ophir (2019) use three different datasets and a combination of topic modeling, network analysis and community detection algorithms to analyze frames. Their datasets consist of political newspaper articles and wire service coverage $(\mathrm{N}$ $=8,337$ ), newspaper articles on foreign nations (2010-2015, $\mathrm{N}=18,216)$ and health-related newspaper coverage (2009-2016, $\mathrm{N}=5$,005). Lastly, $\mathrm{Vu}$ and Lynn (2020) analyze newspaper coverage of the Rohingya crisis (2017-2018, $\mathrm{N}=747)$ concer- ning frames.

\section{REFERENCES/COMBINATION WITH OTHER} METHODS OF DATA COLLECTION

While most approaches only rely on automated data collection and analyses, some also combine automated and manual coding. For example, a recent study by Vu and Lynn (2020) proposes to combine semantic networks and manual coding to identify frames.

\section{REFERENCES}

Cappella, J. N., \& Jamieson, K. H. (1997). Spiral of cynicism: The press and the public good. New York: Oxford University Press.

Entman, R. M. (1991). Framing U.S. coverage of international news: contrasts in narratives of the KAL and Iran Air incidents. Journal of Communication, 41(4), 6-7.

van der Meer, T. G. L. A., Kroon, A. C., Verhoeven, P., \& Jonkman, J. (2019). Mediatization and the disproportionate attention to negative news: The case of airplane crashes. Journalism Studies, 20(6), 783-803.

Walter, D., \& Ophir, Y. (2019). News frame analysis: an inductive mixed-method computational approach. Communication Methods and Measures, 13(4), 248-266.

Vu, H. T., \& Lynn, N. (2020). When the news takes sides: Automated framing analysis of news coverage of the rohingya crisis by the elite press from three countries. Journalism Studies. Online first publication. doi:10.1080/1461670X.2020.1745665 


\begin{tabular}{|c|c|c|c|c|}
\hline Author(s) & Sample & Procedure & 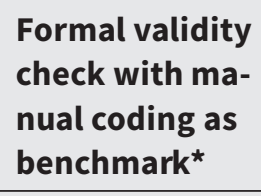 & Code \\
\hline $\begin{array}{l}\text { Vu \& Lynn } \\
(2020)\end{array}$ & Newspaper articles & $\begin{array}{l}\text { Semantic net- } \\
\text { works; manual } \\
\text { coding }\end{array}$ & Reported & Not available \\
\hline $\begin{array}{l}\text { van der Meer } \\
\text { et al. } \\
(2019)\end{array}$ & Newspaper articles & $\begin{array}{l}\text { LDA topic mo- } \\
\text { deling; k-means } \\
\text { clustering }\end{array}$ & Not reported & Not available \\
\hline $\begin{array}{l}\text { Walter \& } \\
\text { Ophir } \\
(2019)\end{array}$ & $\begin{array}{l}\text { (a) U.S. newspapers } \\
\text { and wire service } \\
\text { articles } \\
\text { (b) Newspaper } \\
\text { articles } \\
\text { (c) Newspaper } \\
\text { articles }\end{array}$ & $\begin{array}{l}\text { LDA topic mo- } \\
\text { deling, network } \\
\text { analysis; com- } \\
\text { munity detec- } \\
\text { tion algorithms }\end{array}$ & Not reported & $\begin{array}{l}\text { https://github.com/ } \\
\text { DrorWalt/ANTMN }\end{array}$ \\
\hline
\end{tabular}

* Please note that many of the sources listed here are tutorials on how to conducted automated analyses - and therefore not focused on the validation of results. Readers should simply read this column as an indication in terms of which sources they can refer to if they are interested in the validation of results. 